\title{
CARCASS PHYSICAL COMPOSITION AND MEAT QUALITY OF HOLSTEIN CALVES, TERMINATED IN DIFFERENT FINISHING SYSTEMS AND SLAUGHTER WEIGHTS
}

\author{
Composição física da carcaça e qualidade da carne de bezerros da raça holandesa, \\ terminados em diferentes sistemas de terminação e pesos de abate
}

\author{
Priscila Vincenzi dos Santos ${ }^{1}$, Wagner Paris², Luís Fernando Glasenapp de Menezes', \\ Douglas Vonz ${ }^{1}$, Magali Floriano da Silveira ${ }^{1}$, Jessica Tubin ${ }^{1}$
}

\begin{abstract}
The Brazil sacrifices many dairy calves at birth, which can become a very serious problem merchandising. The objective of this experiment was to evaluate the physical carcass composition and meat quality characteristics of Holstein calves in feedlot or pasture with supplementation, slaughtered at $140,180,220$ or $260 \mathrm{~kg}$ body weight. In the early termination calves had on average 57 $\mathrm{kg}$ and 58 days of age. The confined animals were fed forage (corn) and concentrated, in the ratio of 40:60 and concentrated pasture supplemented with $1 \%$ body weight. The experimental design was completely randomized in a factorial $2 \times 4$ (two feeding systems $\mathrm{x}$ four slaughter weights). It was observed a significant interaction between slaughter weight and finishing system only for the texture of the meat. The finished animals on pasture showed improved texture with increased weight, whereas the confined animals did not affect the weight. Animals finished on pasture had higher muscle percentage $(69.48 \%$ vs $66.57 \%)$, and lower fat percentage $(9.58 \%$ and $9.75 \mathrm{~kg}$ vs $13.20 \%$ and $13.08 \mathrm{~kg}$ ) compared to confined animals. There was a linear increase in the total amount of muscle, bone and fat, muscle / bone ratio, compared edible portion / bone, palatability and juiciness when increased slaughter weight. The percentage of bone and meat coloring decreased linearly with the increase of slaughter weight. The proportion of muscle and fat, showed quadratic behavior. The animals of dairy breeds are excellent producers of lean meat, with good smoothness, flavor and juiciness.
\end{abstract}

Index terms: Fat, tenderness, muscle, marbling, veal.

\section{RESUMO}

O Brasil sacrifica muitos bezerros de origem leiteira ao nascer, o que pode se tornar um problema mercadológico bastante sério. O objetivo deste experimento foi avaliar a composição física da carcaça e as características qualitativas da carne de bezerros holandeses terminados em confinamento ou em pastagem com suplementação, abatidos aos 140;180;220 ou $260 \mathrm{~kg}$ de peso corporal. No início da terminação, os bezerros apresentavam em média $57 \mathrm{~kg}$ e 58 dias de idade. Os animais confinados foram alimentados com volumoso (silagem de milho) e concentrado, na proporção de 40:60 e os da pastagem suplementados com concentrado a $1 \%$ do peso corporal. O delineamento experimental foi o inteiramente casualizado, em arranjo fatorial 2 x 4 (dois sistemas de terminação x quatro pesos de abate). Foi observada interação significativa entre peso de abate e sistema de terminação somente para a textura da carne. Os animais terminados em pastagem apresentaram melhor textura com o aumento do peso, enquanto que os animais confinados o peso não influenciou. Animais terminados a pasto apresentaram maior percentagem de músculo $(69,48 \%$ contra $66,57 \%)$, menor percentagem e quantidade de gordura $(9,58 \%$ e $9,75 \mathrm{~kg}$ contra $13,20 \%$ e $13,08 \mathrm{~kg}$ respectivamente) em relação aos animais do confinamento. Houve crescimento linear para a quantidade total de músculo, osso e gordura, relação músculo/osso, relação porção comestível/osso, palatabilidade e suculência quando se elevou o peso de abate. O percentual de osso e a cor da carne decresceram linearmente com o aumento do peso de abate. A percentagem de músculo e gordura apresentaram comportamento quadrático. Os animais de raças leiteiras são excelentes produtores de carne magra, com boa maciez, palatabilidade e suculência.

Termos para indexação: Gordura, maciez, músculo, marmoreio, vitela.

(Received in july 17, 2013 and approved in august 18, 2013)

\section{INTRODUCTION}

The southern region of Brazil has the third largest dairy herd in the country, about 4.025.083 milked cows, behind only the Southeast and Northeast region (INSTITUTO BRASILEIRO DE GEOGRAFIA E ESTATÍSTICA - IBGE, 2010). But most of the country's dairy farms the males continue being a problem for the producer, by competing with the activity itself because they need to ingest significant amounts of milk in the initial phase of its development.

In some countries, the use of dairy calves for beef production is a reality, representing a significant portion of the meat consumed by the population (EMPRESA DE 
PESQUISA AGROPECUÁRIA - EMBRAPA, 2007). The economic exploitation of these animals should be based on a number of strategies to increase weight gain, however without charging the cost of its breeding. Nowadays, we seek the improvement of rational dairy male, because it is believed it can substantially contribute to the economic outlook for the national livestock and meat supply, avoiding price oscillations and idleness of slaughterhouses (RODRIGUES FILHO et al., 2003).

Moreover, the beef needs to be more competitive in relation to the meat from other species, especially in the qualitative aspects in order to captivate the Brazilian consumer and intensify competition in the foreign market (ARBOITTE et al., 2004). Since the current consumption patterns require meat from young animals, which ensures the quality and increases the importance of finishing animals (PACHECO et al., 2006). Therefore, the notorious importance of using finishing systems that enable the efficient use of male calves from the dairy breeds to increase the production of meat to avoid the waste of a promising source of income to small farmers and solve a problem of animal welfare by avoiding disposal of these animals at birth.

Thus, the objective of this study was to evaluate the best finishing system for meat quality and carcass and study the effect of different slaughter weights on the physical carcass composition and meat quality characteristics of Holstein calves.

\section{MATERIALS AND METHODS}

The experiment was carried out in the experimental area of the Dois Vizinhos campus of the Federal Technology University of Paraná (UTFPR), located in the southwest region of Paraná state, from June 2011 to April 2012. We used 43 Holstein calves, steers, aging 58 days and average weight of $57 \mathrm{~kg}$, which were randomly divided into two finishing systems: feedlot or pasture. Within each system, they were distributed into four groups with stipulated weight (140, 180, 220 and $260 \mathrm{~kg}$ of body weight).

The adjustment period to the facilities and employee management system lasted 15 days. At weaning, the animals received injectable $\mathrm{ADE}$ vitamin, they received albendazole treatment and were weighed after a fasting period of 16 hours. The animals were neither castrated nor dehorned and were vaccinated against foot-and-mouth disease according to the official calendar. The control of parasitic infections was performed by application of Ivermectin to $1 \%$ in all animals on the day of entry stage of the experiment; new applications being made every 28 days, during the periodic weighings.
Twenty-three animals were kept in individual stalls and fed a diet consisting of corn silage like forage with 10.4 and $60.5 \%$ of crude protein (CP) and total digestive nutrients (NDT) respectively mixed with commercial concentrate pellet with $18 \% \mathrm{CP}$ and $70 \% \mathrm{TDN}$, in a ratio of 40:60. The diet was formulated based on nutritional requirements established by the NRC (2001), for an expected daily weight gain of $1.0 \mathrm{~kg}$. The twenty remaining animals were finished on oat (Avena sativa) intercropped with ryegrass (Lolium multiflorium) from $07 / 09 / 11$ to $10 / 05 / 11$, African Star (Cynodon nlemfuensis) from 10/06/11 to 12/ 06/11 and millet (Pennisetum glaucum) from 12/07/11 to $04 / 12 / 12$, and they received concentrate supplementation at $1 \%$ of body weight, with the same composition of ration fed to feedlot plus free access to water and mineral salt. The grazing system used was continuous with supply control in $10 \%$ of body weight, enabling the selection of more nutritious parts to the animals. Samples of hand plucking presented $\mathrm{CP}$ and TDN of $20 \%$ and $56 \%$ respectively.

The feeding of the confined animals was split into two meals a day. Half of it was given at 9 o'clock and the remaining at 4 o'clock. It was maintained to a spare margin of $10 \%$ of the food offered, being the remains of the previous day weighed to estimate consumption. The weighings were taken every 28 days with a 16-hour-fasting of food and water and, as the animals of each treatment reached their slaughter weight, they were slaughtered in a slaughterhouse installed at UTFPR - Dois Vizinhos campus. Right before being slaughtered, each animal was weighed and presented the following average slaughtered 144.6, $179.5,227.5$ or $260.5 \mathrm{~kg}$ of body weight.

After the slaughter, the two half carcasses were washed, identified and cooled for 24 hours at $2{ }^{\circ} \mathrm{C}$. In the right half cold carcass, a section between 11-12th rib was taken, called "section $\mathrm{HH}$," according to the methodology proposed by Hankins and Howe (1946) and adapted by Müller (1987). From that section, a physical separation of the tissues in muscles, fat and bone was carried out for determination of the total quantity and percentage in relation to the cold carcass. In that same section, at the height of the 12th rib, on the exposed face of the muscle Longissimus dorsi, subjective evaluations of color, texture and marbling of the meat were made, after at least 30 minutes exposure to air assigning scores according to the methodology described by Müller (1987). The samples of muscle Longissimus dorsi were taken from the sectioned pieces were identified, vacuum packed and wrapped with brown paper, and immediately frozen at $-18{ }^{\circ} \mathrm{C}$. From the 
samples which were still frozen, two slices of $2.5 \mathrm{~cm}$ thickness were removed, the slice A was weighed and frozen to determine the loss during thawing, and after the cooking at an internal temperature of $70{ }^{\circ} \mathrm{C}$ for 15 minutes to determine the loss in the process of cooking. In the same slice, after the cooking, it was performed a sensorial evaluation of meat (tenderness, juiciness and palatability) by five tasters who attributed a value from 1 (meat extremely tough and unpalatable without juiciness) to 9 (extremely soft meat, flavorful and juicy) as Müller (1987). After baking the slice $B$, three samples of $1 \mathrm{~cm}^{2}$ were taken, in the perpendicular direction to the muscle fibers, and in each two readings were performed by Warner Bratzler Shear device to determine the shear force of the meat.

The mathematical model used in the study is described below by having the initial weight of the animals as a covariate:

$$
\mathrm{Yijkl}=\mu+\mathrm{PIK}+\mathrm{STi}++\mathrm{PAJ}\left(\mathrm{ST}^{*} \mathrm{PA}\right) \mathrm{ij}+\mathrm{Eijkl},
$$

Where, Yijkl $=$ dependent variables, $\mu=$ average of all observations; Pik = effect of the k-th initial weight; STi = effect of the ith- termination system (pasture and feedlot); $\mathrm{PAJ}=$ effect of the jth weight slaughter $(\mathrm{ST} * \mathrm{PA}) \mathrm{ij}=$ interaction between termination system and slaughter weight; Eijk = random residual error.

The data were subjected to analysis of variance, and when statistical difference was found, it was performed the polynomial regression analysis for the slaughter weight, and comparison of means for finishing systems at $5 \%$ significance. All the statistical analyzes were performed by using SAS (2000).

\section{RESULTS AND DISCUSSION}

It was noticed a significant interaction $(\mathrm{P}<0.05)$ between slaughter weight and finishing system only for meat texture. The other characteristics will be discussed separately.

The confined animals had higher $(\mathrm{P}<0.05)$ percentage of fat weight than the ones finished on pasture (Table 1). This result is due to the higher energy intake, because the diet of animals confined presented $66 \%$ of TDN, while pasture based diet was approximately $60 \%$ of TDN, in addition to less physical effort required and, consequently, energy expenditure for maintaining the animals confined in comparison to those kept in pasture. The animals kept in pasture had higher $(\mathrm{P}<0.05)$ percentage of muscle in relation to the confined, according to Vaz et al. (2007), the percentages of the carcass tissues are relative units, in other words, the increase in the percentage of a tissue results in a relative decrease of other important tissue of interest. So the fact that there is a small percentage of more fat in the carcass of the feedlot animals follows that the other percentages, mainly the muscle one, are relatively lower in this treatment.

The rate and amount of bone was similar $(\mathrm{P}>0.05)$ among finishing systems (Table 1), as well as the amount of muscle due to the similarity in carcass weight. There was no significant difference in muscle relation: bone ratio

Table 1 - Means and standard errors for carcass physical composition, color and marbling of the muscle Longissimus dorsi of Holstein bovine finished in different systems.

\begin{tabular}{|c|c|c|c|c|}
\hline \multirow{2}{*}{ Variables } & \multicolumn{2}{|c|}{ Finishing systems } & \multirow{2}{*}{$\mathrm{CV}(\%)$} & \multirow{2}{*}{$\mathrm{P}$} \\
\hline & Feedlot & Pasture & & \\
\hline Muscle, kg & 65.53 & 67.80 & 9.18 & 0.2678 \\
\hline Bone, kg & 18.77 & 19.40 & 10.68 & 0.3514 \\
\hline Fat, kg & 13.08 & 9.75 & 18.86 & $<0.0001$ \\
\hline Muscle, $\%$ & 66.57 & 69.48 & 5.68 & 0.0289 \\
\hline Bone, $\%$ & 19.42 & 20.08 & 10.66 & 0.3468 \\
\hline Fat, \% & 13.20 & 9.58 & 17.91 & $<0.0001$ \\
\hline Relation muscle: bone & 3.49 & 3.50 & 15.67 & 0.9426 \\
\hline Edible portion: bone & 4.18 & 3.98 & 14.27 & 0.3002 \\
\hline Color, points ${ }^{1}$ & 3.89 & 4.26 & 19.07 & 0.1596 \\
\hline Marbling, points ${ }^{2}$ & 2.44 & 1.73 & 55.40 & 0.0705 \\
\hline
\end{tabular}

${ }^{1}$ Color: 1 = black, $2=$ dark red, $3=$ slightly dark red, $4=$ red, $5=$ red.

${ }^{2}$ Marbling: $1-3=$ traces, $4-6=$ mild, 7-9 = small, 10 to $12=$ medium; $13-15=$ moderate, $16-18=$ abundant. 
and the portion of muscle + fat: bone among treatments. According to Miotto et al. (2012) for the meatpacking industry, it is important to seek better relations muscle:bone and muscle + fat: bone because these tissues comprise the marketable portion of the carcass, determining best yields in the boning.

The color of the meat did not differ $(\mathrm{P}>0.05)$ with the use of the pasture or feedlot calves in termination, which ranged from "slightly dark red" to "red", most likely because both diets had concentrated in its composition, this being the main responsible for the change in color of the meat (MISSIO et al., 2010). In this paper, the score of the color of the meat matches the intermediate color between "red" and "slightly dark red", being still considered good by the consumer.

The finishing systems did not affect $(\mathrm{P}>0.05)$ the amount of intramuscular fat or marbling of the meat, classified as "less features" and "traces". The lack of difference may be due to the high coefficient of variation obtained (55.40\%), since the probability level of $7.05 \%$ was observed. The low amount of marbling observed in this study may be explained by the reduced slaughter age of the animals, was not sufficient to deposit intramuscular and subcutaneous fat. Vaz et al. (2007) and Menezes et al. (2010) also found no influence of the power system in the degree of intramuscular fat in beef and beef breeds. According to Schaefer (2005), dairy cattle have more lean meat, producing a carcass with about 25 to $30 \%$ less fat than beef breeds, which is important for consumers interested in a meat with low fat.

In a study conducted in Germany, Dannenberger et al. (2006) compared the Simmental and Holstein beef cattle, fed on pasture or in Feedlot, and found that intramuscular fat in Simmental cattle fed on pasture was reduced to $1.5 \%$, compared to the confined (2.6\%), while for the Holsteins animals it was not found effect of diet on intramuscular fat content of muscle Longissimus dorsi, with values of 2.3 and $2.7 \%$ for grazing and Feedlot, respectively. In Uruguay, Realini et al. (2004) found higher intramuscular fat content in Hereford and Hereford $\mathrm{x}$ Holstein, fed in Feedlot compared with animals fed on pasture.

The losses in the thawing and cooking processes were not affected by the finishing systems used (Table 2), with mean values of 13.92 and $24.69 \%$ respectively.

Such losses are influenced by the degree of marbling because the water holding capacity of the meat is directly linked to the fat present in it, as well as factors related to cooling of carcasses after slaughter, and especially the speed of the $\mathrm{pH}$ fall during the glycolysis post-mortem by the occurrence of higher levels of preslaughter stress (COSTA et al., 2002; LAWRIE, 2005). According to French et al. (2001), the supplementation with grains compared to growing and finishing exclusive in grazing can reduce the loss in cooling the higher deposition of fat in animals that consume longer diets energy. In this study, the meat did not show enough fat in any treatment, values being observed fat insufficient to reduce the losses of cooling.

The tenderness measured by shear force in a Warner Bratzler Shear and by the taste panel showed no difference $(\mathrm{P}>0.05)$ for finishing systems, with ratings between "soft and very soft" (Table 2). In line with Maciel et al. (2011) the hardness or softness of the meat can be divided into at least two principal components, the hardness considered residual caused by the connective tissue (collagen and elastin) and other proteins and

Table 2 - Means and standard errors for sensory and organoleptic characteristics of meat from Holstein cattle finished in different finishing systems.

\begin{tabular}{|c|c|c|c|c|}
\hline \multirow[t]{2}{*}{ Variables } & \multicolumn{2}{|c|}{ Finishing systems } & \multirow{2}{*}{$\begin{array}{l}\text { CV } \\
(\%)\end{array}$} & \multirow[t]{2}{*}{$\mathrm{P}$} \\
\hline & Feedlot & Pasture & & \\
\hline Thawing loss, $\%$ & 13.99 & 13.84 & 27.98 & 0.9030 \\
\hline Cooking loss, $\%$ & 23.86 & 25.52 & 15.68 & 0.1815 \\
\hline Softness, points $*$ & 7.44 & 7.03 & 14.09 & 0.2213 \\
\hline Shear Strength, $\mathrm{kgf} / \mathrm{cm}^{3} * *$ & 3.50 & 4.31 & 43.30 & 0.1337 \\
\hline Palatability, points * & 5.65 & 6.19 & 16.36 & 0.0853 \\
\hline Juiciness, points * & 6.00 & 5.84 & 14.18 & 0.5597 \\
\hline
\end{tabular}

Ciênc. agrotec., Lavras, v. 37, n. 5, p. 443-450, set./out., 2013 
hardness related to the actomyosin complex correlated with the share of calpains and calpastatinas on the breaking of the myofibrils, also influenced by factors such as the age of the animal, whether there was or not preslaughter stress, the temperature of the cold chamber the fat cover which protects the fibers from cold shortening. Further, according to Vaz et al. (2007) the shear force in not matured meat is directly influenced by the content of collagen. The fact that both finishing systems showed no difference in marbling and because of similar age and body weight may explain the similarity for softness found in this study.

Dannenberger et al. (2006) analyzed the Dutch and Simmental cattle carcass finished on pasture or feedlot and slaughtered at $620 \mathrm{~kg}$ live weight, and concluded that the values of shear force were affected by diet, nutrition and grazing resulted in tougher meat in both breeds compared with the meat of the confined animals. Vaz et al. (2007) also found lower shear force in beef cattle feedlot than in pasture $\left(7.27 \mathrm{vs} 9.23 \mathrm{kgf} / \mathrm{cm}^{3}\right.$, respectively). However, older animals were used in both experiments.

The palatability and juiciness were not affected $(\mathrm{P}>0.05)$ by the finishing system with averages of 5.92 points for both. The average score of these characteristics
(5.92 respectively) refers to meat palatability and juiciness above average.

When Rezende et al. (2012) evaluated Dutch crossbred steers slaughtered at 15 months with $395 \mathrm{~kg}$ live weight, they observed that the animals presented more tender meat when they received a high level of supplementation during rearing, regardless the level of concentrate in the finishing. Whereas Missio et al. (2010) observed that the increase of the level of concentrate in the diet did not cause significant changes in meat tenderness, as assessed by the taste panel and shear force, and palatability and juiciness of young bulls finished in feedlot.

Table 3 shows that the total weights of bone, muscle and fat increased with increasing slaughter weight. When evaluating the increase of the three tissues that comprise the carcass, it appears that increasing the slaughter weight from 140 to $260 \mathrm{~kg}$ resulted in increase of $67.23 \%$ on the weight of the bone of the carcass and $91.84 \%$ increase in muscle tissue, indicating that there was still a growth of these tissues due to the biological development of the animals. The increase of the musculature reflects on the higher protein anabolism characteristic of young animals, because the animals are under the anabolic effect of testicular hormones. However, this growth was lower than in the adipose tissue whose increase was $155.5 \%$.

Table 3 - Means and standard errors for carcass physical composition, color and marbling of the muscle Longissimus dorsi of Holstein bovine according to slaughter weight.

\begin{tabular}{|c|c|c|c|c|c|c|c|}
\hline \multirow{2}{*}{ Variables } & \multicolumn{4}{|c|}{ Slaughter weight $(\mathrm{Kg})$} & \multirow[b]{2}{*}{$\mathrm{CV}(\%)$} & \multicolumn{2}{|c|}{ Value $\mathrm{p}^{1}$} \\
\hline & 144.6 & 179.7 & 227.5 & 260.5 & & $\mathrm{~L}$ & Q \\
\hline Muscle, $\mathrm{kg}^{2}$ & 46.72 & 57.16 & 73.15 & 89.63 & 9.18 & $<0.0001$ & 0.1570 \\
\hline Bone, $\mathrm{kg}^{3}$ & 14.16 & 17.40 & 21.10 & 23.68 & 10.68 & $<0.0001$ & 0.2829 \\
\hline Fat, $\mathrm{kg}^{4}$ & 6.09 & 10.02 & 13.99 & 15.56 & 18.86 & $<0.0001$ & 0.0784 \\
\hline Muscle, $\%{ }^{5}$ & 69.07 & 66.74 & 67.09 & 69.20 & 5.68 & 0.0295 & 0.0056 \\
\hline Bone, $\%^{6}$ & 20.88 & 20.40 & 19.43 & 18.30 & 10.66 & 0.0032 & 0.3145 \\
\hline Fat, $\%{ }^{7}$ & 8.95 & 11.79 & 12.71 & 12.12 & 17.91 & 0.5417 & 0.0100 \\
\hline RELMO $^{8}$ & 3.34 & 3.33 & 3.49 & 3.82 & 15.67 & 0.0043 & 0.1170 \\
\hline RELPCO $^{9}$ & 3.76 & 3.91 & 4.15 & 4.49 & 14.27 & 0.0034 & 0.3507 \\
\hline Color, points ${ }^{10} *$ & 4.63 & 4.42 & 3.73 & 3.50 & 19.07 & 0.0017 & 0.8394 \\
\hline Marbling, points ${ }^{11} * *$ & 1.09 & 2.12 & 2.76 & 2.38 & 55.40 & 0.1391 & 0.1633 \\
\hline
\end{tabular}

* Color: $1=$ dark, 2 = dark red, $3=$ slightly dark red, $4=$ red, $5=$ bright red.

** Marbling: 1-3 = traces, 4-6 = mild, 7-9 = small, 10 to $12=$ medium; $13-15=$ moderate, $16-18=$ abundant.

${ }^{1} \mathrm{~L}$ and $\mathrm{Q}$ : order effects on the linear and quadratic increase in slaughter weight.

${ }^{2} \mathrm{Y}^{\wedge}=-10.38845-0.01321 * \mathrm{IW}+0.37633 * \mathrm{SW}\left(\mathrm{r}^{2}=0.92\right),{ }^{3} \mathrm{Y}^{\wedge}=-0.98031+0.07701 * \mathrm{IW}+0.07822 * \mathrm{SW}\left(\mathrm{r}^{2}=0.84\right),{ }^{4} \mathrm{Y}^{\wedge}-3.33568$ $+0.03474 * \mathrm{IW}+0.06587 * \mathrm{SW}\left(\mathrm{r}^{2}=0.62\right),{ }^{5} \mathrm{Y}^{\wedge}=110.30494-0.17252 * \mathrm{IW}-0.38280 * \mathrm{SW}+0.00102 * \mathrm{SW}^{2}\left(\mathrm{r}^{2}=0.37\right),{ }^{6} \mathrm{Y}^{\wedge}=$ $21.85514+0.06025 * \mathrm{IW}-0.02568 * \mathrm{SW}\left(\mathrm{r}^{2}=0,26\right),{ }^{7} \mathrm{Y}^{\wedge}=-18.21958+0.06796 * \mathrm{IW}+0.27047 * \mathrm{SW}-0.00065592 * \mathrm{SW}^{2}\left(\mathrm{r}^{2}=0.23\right)$, ${ }^{8} \mathrm{Y}^{\wedge}=3.14487-0.01635^{*} \mathrm{IW}+0.00573 * \mathrm{SW}\left(\mathrm{r}^{2}=0.25\right),{ }^{9} \mathrm{Y}^{\wedge}=3.60155-0.01704 * \mathrm{IW}+0.00672 * \mathrm{SW}\left(\mathrm{r}^{2}=0.26\right),{ }^{10} \mathrm{Y}^{\wedge}=5.35862+$ $0.01439 * \mathrm{IW}-0.01093 * \mathrm{SW}\left(\mathrm{r}^{2}=0.28\right),{ }^{11} \mathrm{Y}^{\wedge}=2.08$. 
According to the regression equation muscle percentage presented a quadratic behavior decreasing until the weight of $190 \mathrm{~kg}$ thereafter it increased linearly according to the increase of animal weight. On the other hand, the fat percentage had an inverse behavior; it increased until the weight of $220 \mathrm{~kg}$ (Table 3). The percentage of bone decreased linearly, decreasing with the increase of weight, corroborating Carvalho et al. (2003) as the animal grows there is a reduction in the proportion of bone. These results reflect the changes in the proportions of tissues, since even being slaughtered at $260 \mathrm{~kg}$, they were still very young.

An increasing linear behavior was observed for muscle: bone ratio (RELMO) and relation edible portion: bone (RELPCO) (Table 3), reflecting the decreased synthesis of bone tissue with increasing age. The coloring of the meat decreased $(\mathrm{P}<0.05)$ as the weight increased (Table 3 ), varying in rating "red to bright red" to "slightly dark red," which can be considered attractive for consumer, since it is obtained from very early Holstein calves. There is still much prejudice against veal calves, mostly white meat, in the case of the present study, the animals showed intermediate meat coloring because they were fed solid food and forages.

The amounts related to the degree of marbling showed no significant variation in slaughter weight (Table 3).

The different weights of slaughter did not affect $(\mathrm{P}>0.05)$ the thawing (13.91\%) and cooking (24.68\%) losses
(Table 4). This result may be due to deposition of intramuscular fat (marbling), which also did not differ with increasing slaughter weight (Table 3). When evaluating very early Red Angus steers slaughtered at different weights, Several authors emphasize the importance of measuring fluid loss during thawing and cooking, as they are directly associated with the juiciness and flavor of the meat during the tasting (COSTA et al., 2002; KUSS et al., 2009).

The juiciness and flavor of the meat presented a linear increasing behavior with the increase of the slaughter weight. Ranging from "average and tasty" to average and juicy", respectively (Table 4). The highest degree of finishing, marbling and lipid content of the carcass makes the best beef palatability, indicating that the fat present in the interior of muscle cells have flavoring substances (COSTA et al., 2002).

However, even with little fat marbling the meat of Holstein calves presented itself as flavorful and juicy. The tenderness determined by the taste panel and the tenderness measured by Warner-Bratzler Shear were not affected $(\mathrm{P}>0.05)$ by slaughter weight (average of 7.23 points and $3.90 \mathrm{kgf}$ ), the softness was classified between "soft to very soft". These values denote high meat tenderness of dutch veal.

As shown in table 5, there was significant interaction between slaughter weight and finishing system for the texture of the meat, and animal feedlot in the texture was influenced by slaughter weight, averaging 4.4 points, texture classified as "thin".

Table 4 - Means and standard errors for sensory and organoleptic characteristics of meat from Holstein bovine, according to slaughter weight.

\begin{tabular}{|c|c|c|c|c|c|c|c|}
\hline \multirow{2}{*}{ Variables } & \multicolumn{4}{|c|}{ Slaughter weight $(\mathrm{kg})$} & \multirow{2}{*}{$\mathrm{CV}(\%)$} & \multicolumn{2}{|c|}{ Valor $\mathrm{p}^{1}$} \\
\hline & 144.6 & 179.7 & 227.5 & 260.5 & & $\mathrm{~L}$ & $\mathrm{Q}$ \\
\hline Thawing loss, $\%^{2}$ & 15.28 & 13.58 & 12.74 & 14.07 & 27.98 & 0.4373 & 0.2106 \\
\hline Loss cooking, $\%^{3}$ & 26.72 & 25.14 & 22.84 & 24.05 & 15.68 & 0.1219 & 0.3859 \\
\hline Softness, points ${ }^{4 *}$ & 7.03 & 7.36 & 7.01 & 7.55 & 14.09 & 0.6908 & 0.7934 \\
\hline Shear force, $\mathrm{kgf} / \mathrm{cm}^{5} * *$ & 4.83 & 3.63 & 3.26 & 3.89 & 43.30 & 0.3897 & 0.0698 \\
\hline Palatability, points ${ }^{6} *$ & 5.34 & 5.73 & 6.36 & 6.25 & 16.36 & 0.0228 & 0.5241 \\
\hline Juiciness, points ${ }^{7} *$ & 5.31 & 5.97 & 5.87 & 6.53 & 14.18 & 0.0128 & 0.9098 \\
\hline
\end{tabular}

*Tenderness: 1 = extremely tough, extremely tasteless or extremely without juiciness, 2 = very tough, lacking in flavor or poor in juiciness, 3 = hard, little tasty or juicy, $4=$ slightly below average, $5=$ average, $6=$ slightly above average, $7=$ soft, tasty and juicy, $8=$ very tender, very tasty and very juicy; $9=$ extremely tender, extremely juicy and extremely tasty.

** Higher values indicate less tenderness.

${ }^{1} \mathrm{~L}$ and $\mathrm{Q}$ : order effects on the linear and quadratic increase in slaughter weight.

${ }^{2} \mathrm{Y}^{\wedge}=13.91,{ }^{3} \mathrm{Y}^{\wedge}=24.68,{ }^{4} \mathrm{Y}^{\wedge}=7.23,{ }^{5} \mathrm{Y}^{\wedge}=3.90,{ }^{6} \mathrm{Y}^{\wedge}=6.32727-0.03705 * \mathrm{IW}+0.00850 * \mathrm{SW}\left(\mathrm{r}^{2}=0.17\right),{ }^{7} \mathrm{Y}^{\wedge}=3.40052+0.01649 * \mathrm{IW}$ $+0.00786^{*} \mathrm{SW}\left(\mathrm{r}^{2}=0.19\right)$.

Ciênc. agrotec., Lavras, v. 37, n. 5, p. 443-450, set./out., 2013 
Table 5 - Means and standard errors for meat texture according to the termination system and slaughter weight.

\begin{tabular}{lcccccc}
\hline \multirow{2}{*}{ Finishing systems } & \multicolumn{4}{c}{ Slaughter Weight, $\mathrm{kg}$} & \multicolumn{2}{c}{ Value $^{1}$} \\
\cline { 2 - 7 } & 144.6 & 179.7 & 227.5 & 260.5 & $\mathrm{~L}$ & $\mathrm{Q}$ \\
\hline Feedlot $^{2}$ & \multicolumn{9}{c}{ Texture, points* } \\
Pasture $^{3}$ & 4.63 & 4.38 & 4.18 & 4.41 & 0.5459 & 0.4451 \\
Average & 3.69 & 3.65 & 4.97 & 4.41 & 0.0318 & 0.4937 \\
\hline
\end{tabular}

*Texture: $1=$ very thick; $2=$ thick; $3=$ slightly thick; $4=$ thin; $5=$ very thin.

${ }^{1} \mathrm{~L}$ e Q : order effects on the linear and quadratic increase in slaughter weight.

${ }^{2} \mathrm{Y}^{\wedge}=4.40,{ }^{3} \ddot{\mathrm{Y}}=2.77311-0.00318 * \mathrm{IW}+0.00790 * \mathrm{SW}\left(\mathrm{r}^{2}=0.26\right)$.

While the texture of the meat from animals finished on pasture with supplementation showed linear increasing behavior with increasing slaughter weight, it means it was improved with increasing animal weight. This can be explained by differences in growth of connective tissue, or influences age and fitness of the animal and type of the evaluated muscle (HOGG, 1991).

\section{CONCLUSIONS}

Holstein calves finished in feedlot had higher fat content in carcass that those finished on pasture. However, they are excellent producers of lean meat, with good smoothness, flavor and juiciness. The animals finished on pasture showed improved texture with increasing slaughter weight, which may be a good option for meat production.

The increase in slaughter weight of veal provides more juiciness and flavor.

\section{ACKNOWLEDGEMENTS}

To CNPq and Fundação Araucaria for the financial support.

\section{REFERENCES}

ARBOITTE, M.Z. et al. Composição física da carcaça, qualidade da carne e conteúdo de colesterol no músculo longissimus dorsi de novilhos 5/8 nelore - 3/ 8 charolês terminados em confinamento e abatidos em diferentes estádios de maturidade. Revista Brasileira de Zootecnia, Viçosa, v.33, n.4, p.959-968, jul/aug. 2004.

CARVALHO, P.A. et al. Características quantitativas, composição física tecidual e regional da carcaça de bezerros machos de origem leiteira ao nascimento, 50 e 110 dias de idade. Revista Brasileira de Zootecnia, Viçosa, v.32, n.6, p.1476-1483, nov/dec. 2003.
COSTA, E.C. et al. Composição física da carcaça, qualidade da carne e conteúdo de colesterol no músculo Longissimus dorsi de novilhos red angus superprecoces, terminados em confinamento e abatidos com diferentes pesos. Revista Brasileira de Zootecnia, Viçosa, v.31, n.1, p.417-428, Jan./Feb. 2002.

DANNENBERGER, D. et al. Carcass and meat quality of pasture vs concentrate fed German Simmental and German Holstein bulls. Archive Tierz, Dummerstorf, v.49, n.4, p.315-328, jul/aug. 2006.

\section{EMPRESA BRASILEIRA DE PESQUISA AGROPECUÁRIA - EMBRAPA. Produção de Vitelos. Juiz de Fora, April. 2007.}

FRENCH, P. et al. The eating quality of meat of steers fed grass and/or concentrates. Meat Science, Dublin, v. 57, n. 4, p. 379-386, apr. 2001.

HANKINS, O.G.; HOWE, P.E. Estimation of the composition of beef carcass and cuts. Washington: Unite State Department of Agriculture (Technical Bulletin, 926), 1946.

HOGG, B. W. Compensatory growth in ruminants. In: PEARSON, A.M.; DUTSON, T. R. Growth regulation in farm animals: advances in meat research. New York: Elsevier Science Publishers Ltda., p. 103-134, 1991.

\section{INSTITUTOBRASILEIRODE GEOGRAFIA E}

ESTATÍSTICA - IBGE. Sistema de recuperação de informações - SIDRA. Homepage IBGE, Brasília, 2010. Disponível em: <http:/www.sidra.ibge.gov.br>. Acesso em: nov. 2012. 
KUSS, F. et al. Características da carcaça de novilhos não-castrados ou castrados terminados em confinamento e abatidos aos 16 ou 26 meses de idade. Revista Brasileira de Zootecnia, Viçosa, v.38, n.3, p.515522, oct. 2009.

LAWRIE, R. A. Ciência da carne. 6. ed. Porto Alegre: Artmed, 2005. 384p.

MACIEL, M.V. et al. Métodos avaliativos das características qualitativas e organolépticas da carne de ruminantes. Revista Verde de Agroecologia e Desenvolvimento Sustentável, Mossoró, v.6, n.3,p. 17-24, jul/sep. 2011.

MENEZES, L.F.G. et al. Características da carcaça e da carne de novilhos superjovens da raça Devon terminados em diferentes sistemas de alimentação.

Revista Brasileira de Zootecnia, Viçosa, v.39, n.3, p.667676, mar. 2010.

MIOTTO, F.R.C. et al. Farelo de mesocarpo de babaçu (Orbygnia sp.) na terminação de bovinos: composição física da carcaça e qualidade da carne. Ciência Rural, Santa Maria, v.42, n.7, jul. 2012.

MISSIO, R.L. et al. Características da carcaça e da carne de tourinhos terminados em confinamento, recebendo diferentes níveis de concentrado na dieta. Revista Brasileira de Zootecnia, Viçosa, v.39, n.7, p.1610-1617, jul. 2010.

MÜLLER, L. Normas para avaliação de carcaças e concurso de carcaça de novilhos. $2^{\mathrm{a}}$ ed. Santa Maria: Imprensa Universitária, 31p, 1987.

NATIONAL RESEARCHCOUNCIL - NRC. Nutrient requirements of domestic animals. 8.rev.ed.

Washington, D.C.: National Academy Press, 280p., 2001.
PACHECO, P. S. et al. Avaliação econômica da terminação em confinamento de novilhos jovens e superjovens de diferentes grupos genéticos. Revista Brasileira de Zootecnia, Viçosa, v. 35, n. 1, p. 309-320, jan/feb. 2006.

REZENDE, P.L.P. et al. Carcass and meat characteristics of crossbred steers submitted to different nutritional strategies at growing and finishing phases. Ciência Rural, Santa Maria, v.42, n.5, p.875-881, may. 2012.

REALINI, C.E. et al. Effect of pasture vs. concentrate feeding with or without antioxidants on carcass characteristics, fatty acid composition, and quality of Uruguayan beef. Meat Science, Athens, v.66, n. 3, p.567577, mar. 2004.

RODRIGUES FILHO, M. et al. Desempenho e características de carcaça de novilhos de origem leiteira, alimentados com diferentes níveis de concentrado e de cama de frango. Revista Brasileira de Zootecnia, Viçosa, v.32, n.3, p.672-682, may/jun. 2003.

SAS INSTITUTE. SAS/STAT. User's guide: statistics, versão 8.1. 4.ed. Cary: SAS Institute, v.2. 2000.

SCHAEFER, D. M. Yield and quality of Holstein beef. In: Managing \& Marketing Quality Holstein Steers Proceedings. Madison: Wis. Agric. Service Assoc., 2005, p.323-333.

VAZ, F.N. et al. Qualidade da carcaça e da carne de novilhos abatidos com pesos similares, terminados em diferentes sistemas de alimentação. Ciência Animal Brasileira, Santa Maria, v.8, n.1, p.31-40, jan/mar. 2007. 